\title{
Overview of emerging technologies in sprinkler irrigation to optimize crop production
}

\author{
Hong $\mathrm{Li}^{1 *}$, Zakaria Issaka ${ }^{1,2}$, Yue Jiang ${ }^{1}$, Pan Tang ${ }^{1}$, Chao Chen ${ }^{1}$ \\ (1. Research Centre of Fluid Machinery Engineering and Technology, Jiangsu University, Zhenjiang 212013, China; \\ 2. Department of Agricultural Engineering, Tamale Technical University, Northern Region, Tamale, Ghana)
}

\begin{abstract}
Water saving is an essential part of sprinkler irrigation owing to the impact of climate change and rising energy costs. This review highlights the technologies that are emerging in sprinkler irrigation to optimize crop production. While there have been notable advances in irrigation, the continued progress has occurred by the combination of current status with the postulation of new ideas such as conversion of high-pressure sprinkler to low-pressure ones, incorporation of smart controllers in sprinkler irrigation systems. To enhance the adoption of these technologies, research on the dispersion device is needed to improve the performance of impact sprinklers to efficiently operate at low-pressure conditions. It is also important to study how water savings estimates based on water use, irrigated area, longevity of saving, and level of wasteful irrigation prior to the retrofit obtained from field trials can be extrapolated to other areas with different conditions. Research in the development of optimized method for irrigation scheduling is necessary. This review emphasizes that the status of technologies should be considered a continuum, building on earlier knowledge and progress, and hopefully leading toward optimized crop production in sprinkler irrigated areas.
\end{abstract}

Keywords: sprinkler irrigation technologies, smart controllers, crop water demand, crop production DOI: $10.25165 /$ j.ijabe.20191203.4310

Citation: Li H, Issaka Z, Jiang Y, Tang P, Chen C. Overview of emerging technologies in sprinkler irrigation to optimize crop production. Int J Agric \& Biol Eng, 2019; 12(3): 1-9.

\section{Introduction}

In most parts of the world, lack of efficient irrigation methods leads to excessive use of irrigation water, leading to reductions in crop yield. Available data shows that many irrigation systems are inefficient with less than half of the irrigation water on average reaching the crop ${ }^{[1-5]}$. Hence, improvements in irrigation systems remains the key to optimize crop production and sustain future food demands. Irrigation has the potential to increase crop production per ha by 2.3 times higher than those from rainfed areas ${ }^{[6-9]}$.

Sprinklers uses mechanical and hydraulic devices to apply irrigation water to the soil surface. Sprinkler irrigation can apply water, fertilizer and pesticides together with the correct amount and frequency, fertilizer and pesticide efficiency, reduce the occurrence of plant diseases and insect pests, inhibit the growth of weeds, keep the soil aggregate knot, provide good conditions for crop growth, to increase production and improve product quality ${ }^{[10]}$. Hence, it can be concluded that sprinklers can perform better than conventional irrigation methods. As an example, the yield of field crops under sprinkler irrigation could be increased from 10\%-20\%, while economic and vegetable crops could be increased by $30 \%$, respectively ${ }^{[6,11]}$. However, the major challenge that remains

Received date: 2018-04-09 Accepted date: 2019-05-12

Biographies: Zakaria Issaka, $\mathrm{PhD}$ Candidate, research interests: water-saving irrigation theory and technical innovation, Email: issakazak@gmail.com; Yue Jiang, Assistant Professor, research interests: irrigation theory and technical innovation, Email: jy261715267@126.com; Pan Tang, Assistant Professor, research interests: irrigation theory and technical innovation, Email: tangpan19@, 163.com; Chao Chen, Associate Research Fellow, research interests: design of water-saving irrigation equipment, Email: chch3605@ujs.edu.cn.

*Corresponding author: Hong Li, Professor, research interests: design of water-saving irrigation equipment. Research Center of Fluid Machinery Engineering and Technology, Jiangsu University, No.301 Xuefu Road, Zhenjiang 212013, China. Tel: +86-13952891655, Email: hli@ujs.edu.cn. unresolved is that crop foliage remains wet, thus increasing incidence of pests or diseases and foliage burn under sprinkler fertigation. It is also possible that the nutrients may apply to other areas where roots are not active, decreasing fertilizer-use efficiency. Another challenge in sprinkler systems is how to avoid runoff and reduce the effect by the wind. This helps to conserve water consumed by crops and moistens the soil for agricultural activities to be carried out. A properly designed sprinkler irrigation has higher application efficiency that can avoid runoff. Due to the numerous advantages, its adoption is gradually increasing around the world. Its adoption is noted as 13.3, 10.1, 6.8, 1.9, and 0.9 million $\mathrm{m}^{2}$ in Americas, Europe, Asia, Africa, Oceana, respectively ${ }^{[10-12]}$. Because of the rising energy-cost and impact of climate change, there is now the need to saving more water for optimum crop production through sprinkler technologies under low pressure.

With the rising demands on water resources, the use of reclaimed water for irrigation has gained considerable interest in many parts of the world. Irrigation controllers that incorporate soil moisture sensors (SMS) for feedback control can have improved performance, but there has been concern about using SMS with reclaimed water, which can affect the soil dielectric permittivity and thus affect the SMS values. Smart irrigation control systems typically include either a stand-alone controller or an add-on device that interfaces with a conventional clock-type controller. The weather-soil moisture-based technologies incorporated into these devices allow them to function similar to a thermostat. Like a thermostat, the devices permit irrigation to occur when needed rather than on a preset schedule. Regardless of the specific method or technology, the concept is for the appropriate irrigation quantity to be applied at the appropriate time.

The effectiveness of sprinkler irrigation in minimizing water losses requires both selection of appropriate sprinkler hardware and 
implementation of appropriate management for the crop, soil, landscape, and weather conditions. Many types of sprinkler nozzles can be selected for pivoted and lateral-move sprinkler irrigation systems. Nozzles can turn the sprinkler head into other devices that can result in less than $20 \%$ use of the irrigation water ${ }^{[13-16]}$. Such sprinkler nozzles spray the water in multiple streams that fight the wind better with higher uniformity than conventional sprays, particularly under specific operating conditions $^{[17-19]}$.

A major difficulty in sprinkler irrigation is how to achieve higher application efficiency under low pressure conditions, particularly for high pressure sprinklers such as impact sprinklers. Low pressure sprinkler irrigation is gaining momentum, and the sustainability of pressurized irrigation is being compromised. This is particularly important in the case of impact sprinklers for their pressure requirements are higher than pivoted sprinklers. The dispersion device can be optimized and mounted on impact sprinklers to facilitate jet breakup, providing a conducive microclimate for optimum crop production. The present review highlights on major difficulties in sprinkler irrigation technologies for optimizing crop production. Optimization of the fixed dispersion device for impact sprinkler and how water savings estimates obtained from field trials can be extrapolated to other areas with very different conditions is necessary. This could be of practical importance for saving more water under low pressure conditions.

\section{Technologies that are emerging in sprinkler irrigation}

Sprinkler irrigation begun around the 19th century in Germany, Italy, the United States and Russia, the first generation of sprinkler appeared in 1917, but until 1920 the application was limited to watering vegetables crops and orchards ${ }^{[20,21]}$. The initial use of sprinkler irrigation was the fixed sprinkler systems. Rotating sprinklers developed by USA, England, France, Germany and Italy emerged gradually after the 1930s. After world war II, towed, movable, center-pivot, reel traction, self-propelled and other large and medium-sized sprinklers emerged, so that sprinkler irrigation technologies developed rapidly all over the world. Irrigation sprinkler can basically be categorized into low-pressure and high-pressure sprinklers ${ }^{[22-24]}$. Trends in sprinkler technologies show that different countries apply different sprinkler equipment. Every country develops a variety of sprinkler equipment and sprinkler systems according to their prevailing local conditions. For instance, USA promotes the use of center-pivot and self-propelled sprinklers. Russia uses a double cantilever sprinkler, while countries like Australia, France and Germany and many other countries focus on developing hose reel irrigation. Many countries are expanding the single-machine control area to improve its efficiency, and reduce the costs associated with labor and management of sprinkler systems. Fertigation through sprinkler irrigation is also being explored worldwide. Because the cost of energy is rising all over the world, there is now a paradigm shift to replace high pressure sprinklers with low pressure ones, hence efforts are being made to optimize high pressure sprinklers to operate under low pressure conditions as well as the use of smart controllers is gaining interest from irrigators worldwide.

\subsection{Conversion of high-pressure sprinkler to low-pressure}

Impact and fluidic sprinklers are high pressure sprinklers that produce moving streams of water at a large distance of throw.
Impact sprinklers provide either full or half circle application pattern with $12 \mathrm{~m}$ head-to-head spacing ${ }^{[15,21]}$. High-pressure sprinklers disperse water in a concerted stream, which create small water droplets that are easily drifted by the wind and evaporation losses are higher, particularly in arid regions. Sprinklers which have been designed for operating under high pressure conditions should not be used under low pressure conditions. Sprinklers are designed to specification, thus to operate within a specific range of flows and pressures. For instance, operating impact sprinklers with $70 \mathrm{kPa}-100 \mathrm{kPa}$ will result in distortion of the application pattern with lower efficiency ${ }^{[25-29]}$. This make them distribute water with excessively large droplets that causes runoff and soil sealing. Inadequate jet break-up from impact sprinklers occur when operated under low pressure, resulting in a poor water distribution. Operating impact sprinklers under low-pressure conditions leads to uneven water distribution, and waste of irrigation water. For these reasons, it is imperative to mechanically break up the jet with a fixed water dispersion device to improve water distribution under low pressure conditions.

There are several ways to improve the water distribution of sprinklers under a low pressure. For example, an orifice nozzle, non-circular nozzles, vanes and fluidic devices can be installed on these sprinklers ${ }^{[30,31]}$. Li et al. developed a fluidic sprinkler based on the principle of "coanda effect" where water flows from the nozzle into a tube installed in the fluidic component to form low pressure $\operatorname{area}^{[32]}$. Although this application improved the water distribution, but there are still some difficulties in relation to the uniformity of rotation of the fluidic sprinkler. Hence, optimization of the fluidic component is necessary to improve its stability in rotation and lessen the variations in the water distributions. Both impact and fluidic sprinklers are used in a solid set configuration where enough nozzles are fixed to spray water in the area irrigated. They are used on lateral move configurations and operated from 12-24 hours of irrigation time. Although these systems are expensive to install, however they can be automated to reduce the costs associated with labor requirements.

The interest in low pressure sprinkler applications to save irrigation water is gaining momentum. Low pressure sprinklers such as the R3000 and R33 saves money, saves time with higher performance than the brass impact sprinklers ${ }^{[15,21]}$. The R33 sprinkler represent a modern sprinkler with high performance which gives a larger sprinkler range, resistant to the wind and uniform water distribution. With the speed control, the sprinkler can be operated to rotate slowly or fast. For low rotation speed, the sprinkler gives droplet that are wind resistant with a large sprinkler range. However, the fast rotation speed produces a uniform water distribution pattern. Besides it is easy to clean and cost less to maintain. Without a drive arm, the sprinkler creates no riser vibration. It also has a long wear life because no seals or bearings are exposed to water pressure. R33 sprinkler has the advantages of saving money and time compared with other sprinklers ${ }^{[15-26]}$. Low-cost sprinklers maintain the advantages of conventional ones by eliminating the limiting factors to their adoption by smallholders. Examples of such factors include pressure and cost requirements including the complexity in their use and maintenance. Improvements in the design and management of such systems reduces water losses through runoff and soil erosion. But, their usefulness in lessening water losses requires that the operator select the right sprinkler together with better management practices for crops, soil and weather conditions. 
A runoff-potential index was developed to improve the selection of pivoted sprinklers ${ }^{[27]}$. The method was tested for other sprinklers, which showed great differences in the runoff potentials. This means that the runoff index gives an effective way for deciding on the type of sprinkler to use by deciding from the sprinklers with large droplets and ranges.

Pivoted sprinklers have the potential to improve the water distributions in a crop field by managing crop evapotranspiration, which is influenced by factors like type of crop, method of irrigation, climate, and condition of the soil. There is an integrated sensor to monitor soil and plant contained by a wireless communication system that gives inputs for algorithms to control and manage the irrigation system. While the use of site-specific irrigation systems is growing, there is less knowledge of how these systems should be managed and optimized to save the resources needed. Although there is growing interest in low-pressure sprinkler systems with applications within or near the crop canopy to potentially save energy and reduce evaporative losses, their effectiveness can be greatly affected by their increased runoff potential. A soil-independent, quantitative runoff-potential index has been developed by King to facilitate selection of moving spray-plate sprinklers for center pivoted and lateral-move sprinkler irrigation systems ${ }^{[28]}$. The methodology was evaluated for several commercially available sprinkler packages. The results indicated that substantial differences exist, and several packages can have similar runoff potential. The runoff index provides an effective means for comparing sprinkler choices by identifying sprinklers with large droplets and relatively small wetted diameters.

\subsection{Smart irrigation controllers}

Smart irrigation technology promotes healthy and attractive irrigation by improving watering efficiency with new "Smart" technologies such as smart irrigation controllers and rotating sprinkler nozzles. The latest innovation in irrigation is the smart sprinkler controller, a device that gives your plants the right amount of water for the time of year, climate and weather. With smart controllers installed, it is possible to avoid over-watering and excessive run-off by scheduling the amount of irrigation based on the type of landscape and current weather conditions.

(1) Rain sensor: A rain sensor is an irrigation shutoff device that prevents an automatic sprinkler system from turning on during and after a rain storm. Rain shut-off sensors are wired to a sprinkler timer and override the scheduled irrigation when a sensor on the shutoff device detects water ${ }^{[30]}$. When the collected rainwater has evaporated from the sensor, scheduled irrigations resume. Rain shut-off sensors are simple, economical and useful tools for preventing irrigation that would be wasteful. Rain shut-off sensors work best for short off periods. For extended periods, it is more accurate to have sprinkler timer in the "off" position.

(2) Pop-up nozzle: The latest innovation in sprinkler technology are nozzles that turn a standard sprinkler head into a precision device that can water your landscape more efficiently by using $20 \%$ less water ${ }^{[31]}$. These nozzles shoot multi-trajectory, rotating streams that apply water more slowly and uniformly than conventional sprays and rotors, particularly when adjusted for specific site conditions (Figure 1). In addition to reducing water use, the water jetting from these nozzles is more resistant to wind, less likely to mist, and significantly reduces run-off on the irrigated field.

Rotating nozzles compliment that simple principle. Rotating nozzles for pop up spray heads apply water much Not all pop-up spray head bodies are compatible with these nozzles. However, the compatibility list is available for check with the nozzle manufacturers directly, while the weather decides when the sprinklers come on to save water.
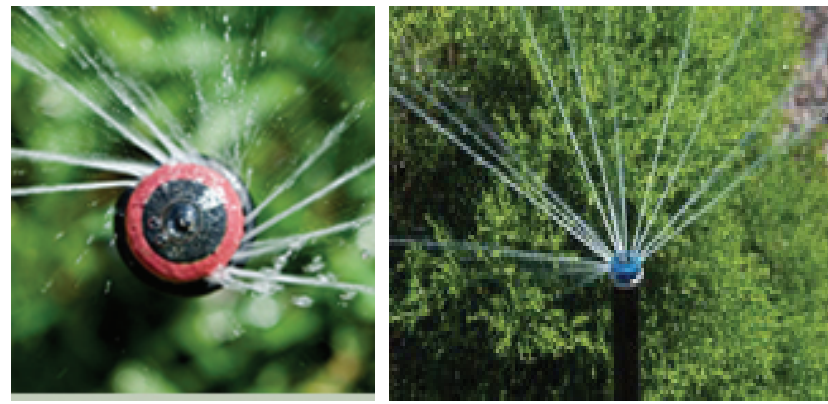

Figure 1 Spray sprinklers with pop-up heads

(3) Soil moisture sensor (SMS): Soil moisture irrigation controllers use water content information from the sensor to either allow or bypass scheduled irrigation cycles on the irrigation timer. The SMS controller has an adjustable threshold setting and, if the soil water content exceeds that setting, the event is bypassed ${ }^{[31,33]}$. The soil water content threshold is set by the user. Another type of control technique with SMS devices is "on-demand" where the controller initiates irrigation at a low threshold and terminates irrigation at a high threshold. Soil moisture control devices can reduce water use on an irrigated field by bypassing scheduled irrigation events but is important to make sure the irrigation schedule is programmed into the irrigation timer correctly. Before setting the irrigation schedule it is important to determine when the water will be applied and how much to apply with each irrigation event.

(4) Mobile connectivity: Several smart controller products incorporate onboard home network connectivity through either wireless networking technology (WiFi) or a local area network (LAN) connection ${ }^{[30,34]}$. The unit can connect to the internet through these. Some models can also create their own WiFi network, which can be connected to even if the device is not connected to an external WiFi network. The purpose of the internet connection varies by manufacturer and model. Many units receive data that are used to adjust watering times (e.g., precipitation) via the internet. Connectivity can also allow the smart controller to be accessed through either a web browser or companion smartphone app managed by the manufacturer as shown in Figure 2.
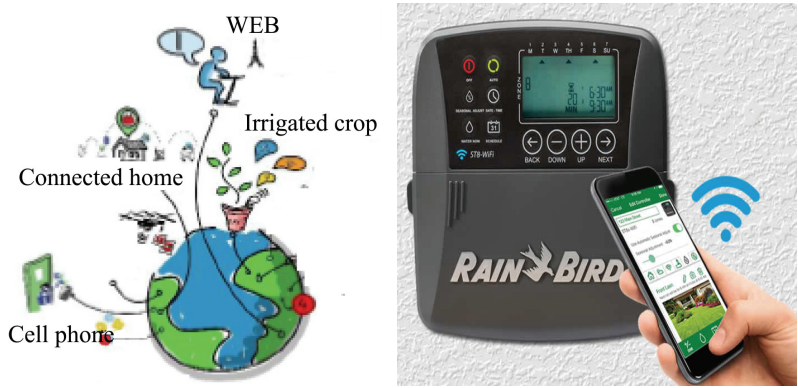

Figure 2 Internet of things (IoT) connectivity

Some devices also incorporate the ability to initiate watering and adjust scheduling through voice commands to an artificial intelligence (AI) assistant (i.e., Google's Assistant ${ }^{\circledR}$ and Amazon's Alexa $\left.{ }^{\circledR}\right)$. Internet and home network connectivity can also enable a smart controller to be part of the Internet of Things (IoT) with a variety of creative ways to manage the controller.

\section{Irrigation scheduling and water management}

Irrigation scheduling calculates the estimated future water 
needs over a period of time to avoid a situation of over or under irrigation. Climatic data is generally used to estimate future water use and to predict the next irrigation time. Irrigation scheduling is important to meet the requirements of deficit irrigation. The method is based on the response of crops to variations in temperature, variations in stem growth rates, lengths of internodes, and the amount of soil moisture. It is also determined in terms of energy balance and the response of crops to the climatic factors. This approach gives a more acceptable yield ratio to water uses, due to proper timing of irrigations. But the difficulty lies in how to separate the influence of such method from other good practices related to the scheduling. In automated sprinkler systems, the need for field soil water sensors is enhanced, however a major difficulty is the specific benefits derived from such scheduling practices. Software inputs vary by crop, but nearly all scenarios require root depth, irrigation rate, and soil type. Similarly, a variety of output information is available to better serve the needs of irrigators.

All the weather-based products reviewed operate on the principle of scheduling irrigation as a function of weather conditions. Most of the products use real-time or historical weather data to schedule irrigation based on ET, which is a function of weather conditions and plant type. ET is defined as the quantity of moisture that is both transpired by a plant and evaporated from the soil and plant surfaces ${ }^{[35]}$. The American Society of Civil Engineering's (ASCE) standardized reference $E T_{\text {crop }}$ equation parameters are maximum and minimum air temperature, net solar radiation, average vapor pressure, and average wind speed ${ }^{[23]}$. Vapor pressure can be calculated from humidity, dry and wet bulb, or dew point data; and solar radiation can be derived from pyranometer or sunshine recorder data. The standardized reference ET equation is widely recognized as one of the best methods for estimating $E T_{\text {crop. }}$ Other less accurate equations also are used that require only temperature and solar radiation parameters, and solar radiation is sometimes estimated as an average value based on historical data for a given site latitude. The problem with using estimated solar radiation values is that significant variability due to cloud cover is neglected, and solar radiation is obviously an important parameter in $E T_{\text {crop }}$ calculation. Some of the products evaluated use these empirical $E T_{\text {crop }}$ equations in their scheduling algorithms. It is significant to consider which equation is used about $E T_{\text {crop }}$ estimation accuracy, or what parameters are measured if the equation used is not referenced.

Specifically, some weather stations do not measure radiation directly but calculate it from other parameters, while some stations are not properly located for $E T_{\text {crop }}$ parameter data collection. Certain products reviewed use onsite temperature measurements combined with historic monthly $E T_{\text {crop }}$ or solar radiation data in the daily $E T_{\text {crop }}$ calculation. The historic data used are a function of the site location. An obvious consideration with this technique is the accuracy of the historic data relative to a specific site. In one case, only five sets of data are available for the entire of USA. Several of the products reviewed calculate $E T_{\text {crop }}$ using a full set of remotely collected data from local weather stations or a network of weather sensors. The weather station data are collected from public and/or private weather stations. The weather station and sensor network data are processed by a centralized computer server and transmitted to the irrigation sites. There are ongoing service provider costs associated with the operation of the weather stations, sensor networks, computers, and information transmission systems associated with these products. These costs either are absorbed by water entities or are paid by the users. In some cases, study results were submitted by manufacturers showing accurate $E T_{\text {crop }}$ calculation and/or significant water conservation associated with their product as discussed under the product descriptions in this report. In addition to the SWAT testing previously discussed, a science-based evaluation of four of the weather-based products reviewed was conducted by the University of California Cooperative Extension in 2003, and the results are reported $b^{[45]}$.

A linear relationship exists between crop yield and crop evapotranspiration $\left(E T_{\text {crop }}\right)$ for crops like maize, sorghum, cassava, sugarcane, barley etc ${ }^{[33]}$. The effect of water stress is commonly seen in low water potentials, obstructs photosynthesis, resulting in stunted growth in crops. Studies show that crop yield can be maximized and grain quality improved, while significantly reducing irrigation water quantity ${ }^{[35]}$. Crop water demand indicates the amount of water required to replace the losses due to evapotranspiration, from the time of planting a specific crop to the time it is harvested for a specific climatic condition, and suitable soil water conditions ${ }^{[35,36]}$. During its growth, every crop needs a specific amount of water according the growth stage, hence it is crucial to evaluate crop water demands to know the deficits in water needed due to insufficient rainfalls or moisture in the soil. In relation to climatic factors and total growth period, a particular crop requires a minimum amount of water to meet the maximum evapotranspiration $^{[4,39,46]}$. Figure 3 presents a graph of crop coefficient $\left(k_{c}\right)$ against number of days after planting. The $k_{c}$ values are specific to each crop and changes according to the growth stages. The crop water demands are low in the early vegetative period of $20 \mathrm{~d}$ after planting (initial stage), the crop water demands are low $\left(-10 \%\right.$ of $\left.\mathrm{ET}_{\max }\right)$. The $\mathrm{ET}_{\max }$ values are high $\left(50 \%-60 \%\right.$ of $\mathrm{ET}_{\max }$ ) during the flowering period (crop development) when leaf area is maximum. Thereafter, the water requirement from 60-80 days after planting stays fairly constant and decline from this point until it reaches $120 \mathrm{~d}$ when it is harvested (late-season stage).

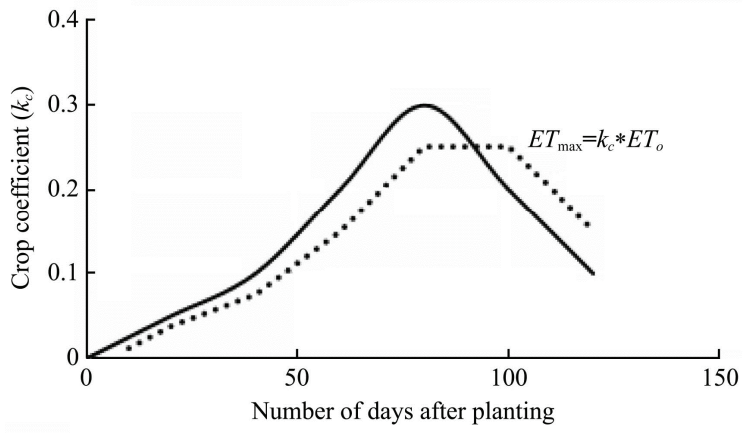

Figure 3 Relationship between crop water demand and growth stages $^{[23]}$

Sprinkler irrigation systems are designed to meet water deficits and to ensure adequate water supply to crops at the critical stages of growth. However, farmers need to be equipped with the requisite knowledge of the time and the correct amount of water to apply to meet crop water needs. For example, the unavailability of water during the early growth stage produces many tubers, which are visible in cylindrical tubers compared with the round variety ${ }^{[35,40,41]}$. Deficits in water during this stage with the application of water leads to cracks in tubers. The amount of dry matter also rises during the maturing time when water is unavailable, conversely, frequent water applications leads to disfigurements in tubers. Hence, proper timing of water 
applications can save between one and three irrigations before harvest time ${ }^{[42]}$. The calculation formula for crop water demand $\left(C W D_{i}\right)$ according to Food and Agriculture Organization (FAO) is defined as:

$$
C W D_{i}(\mathrm{~mm})=\sum_{i=0}^{n}\left(k c_{i} E T_{o}-P_{e}\right)
$$

where, $k c_{i}$ is crop coefficient at a particular growth stage $t ; P_{e}$ is the effective rainfall, $T$ is total growth period, which is the sum of the growth periods for the initial, crop development, midseason and harvest stages.

Reference evapotranspiration $\left(E T_{o}\right)$ of a crop is determined using Penman-Monteith method and CROPWAT software ${ }^{[37]}$. CROPWAT is a computer software that calculates $E T_{o}$, crop water and irrigation amount according to the design and management practices of an irrigation system. It improves irrigation practices through proper planning of water applications under variable conditions ${ }^{[37,43]}$. The method incorporate climatic data of radiation, temperature of the air, humidity, and speed of the wind in the computation. FAO CROPWAT uses $E T_{o}$ and crop water demand data to model crop water uses under different conditions such as climate, crop, and soil ${ }^{[40,44,45]} . \quad E T_{o}$ is defined as:

$$
E T_{o}(\mathrm{~mm} / \text { day })=\frac{0.408 \Delta\left(R_{n}-G\right)+\gamma\left(\frac{900}{T+273}\right) u_{2}\left(e_{s}-e_{a}\right)}{\Delta+\gamma\left(1+0.34 u_{2}\right)}
$$

where, $R_{n}$ is the net radiation $\left(\mathrm{M} \cdot \mathrm{Jm}^{-2} \cdot \mathrm{d}^{-1}\right)$; $G$ is the soil heat flux density $\left(\mathrm{MJ} \mathrm{J}^{-2} \mathrm{~d}^{-1}\right) ; T$ is the mean daily air temperature at $2 \mathrm{~m}$ high $\left({ }^{\circ} \mathrm{C}\right) ; u^{2}$ is the speed of the wind at $2 \mathrm{~m}$ high $\left(\mathrm{m}^{-1}\right)$; es is the saturated vapor pressure $(\mathrm{kPa}), e a$ is the actual vapor pressure $(\mathrm{kPa})$; $e s-e a$ is the deficit in saturated vapor pressure $(\mathrm{kPa}) ; \Delta$ is the slope of curve of vapor pressure $\left(\mathrm{kPa}^{\circ} \mathrm{C}^{-1}\right) ; \gamma$ is the psychrometric constant $\left(\mathrm{kPa}^{\circ} \mathrm{C}^{-1}\right)$. The calculation formula for the total irrigation water demand $\left(T C W D_{i}\right)$ is given as;

$$
T C W D_{i}\left(\mathrm{~m}^{3}\right)=E T_{c} \times A
$$

The crop evapotranspiration in the equation above is also given by

$$
E T_{c}=k_{c} \times E T_{o}
$$

where, $A$ is the land area to be irrigated $\left(\mathrm{m}^{2}\right) ; E T_{C}$ is the crop evapotranspiration $(\mathrm{mm} / \mathrm{d}) ; E T_{O}$ is the reference crop evapotranspiration $(\mathrm{mm} / \mathrm{d})$ and $K_{c}$ is the coefficient of the given crop.

Although modern technologies for scheduling irrigation has existed for many years, the long-term and consistent adoption of appropriate irrigation scheduling has been dismal ${ }^{[44,45]}$. To facilitate better adoption rates and improved irrigation scheduling developed a software application (i.e., smartphone and tablet app) to provide real-time irrigation schedules for various crops (avocado, citrus, cotton, peanut, strawberry, urban turf, cabbage, squash, tomato, and watermelon) in the southeastern $\mathrm{US}^{[46]}$. The application can use real-time weather data from both the Florida Automated Weather Network and the Georgia Environmental Monitoring Network to calculate $\mathrm{ET}_{\text {crop }}$ using a water balance method for scheduling irrigation. The software inputs vary by crop, but nearly all scenarios require root depth, irrigation rate, and soil type. Similarly, a variety of output information is available to better serve the needs of irrigators. Many areas in the world are experiencing water shortages, and irrigators often cannot meet the full crop water needs using their current irrigation and cropping system scenarios. As a result, many producers are implementing strategies such as deficit irrigation to address water shortages. The CERES-Maize crop model was used to examine several deficit-irrigation strategies for corn production in southwest Kansas $^{[46]}$. Their modeling combined experimental results from field studies and long-term weather data to evaluate minimum-allowable depletion for corn, the optimum level of crop available soil water at planting, and the irrigation season termination criteria. They found that irrigation scheduling based on a $50 \%$ plant-available soil water threshold maximized net returns compared to initiating irrigation at a greater soil water content, that it was important to have adequate soil water reserves at planting.

For famers to for farmers to adopt crops and sprinkler technologies that are adaptable to the expected water demands, two possible options are possible. First, irrigation managers can deliver more water available to each farmer. Farmers thereafter collect the water into fields depending on the quantity needed. The method involves less effort from system managers but does not lead to efficient water uses. Second, the managers can pump water to each field depending on the amount of water needed by farmers. The approach requires that the managers have information on the water demands of farmers with good control of water supply, and the flexibility to vary the supply. With this approach, the efficiency to manage and supply water are higher. The rising need for water requires managers to save the limited water available. Methods by which managers solicit information on farmers' water needs include negotiation with farmer groups over seasonal plans in relation to identify the crops to be irrigation and when to apply water before each season. This approach needs managers to project farmers' water needs at fixed times during the entire growth period ${ }^{[47-49]}$. These approaches only estimated actual crop water demands. However, perfect knowledge of crop water needs is impossible where the population of farmers are a large because of the variations in crop varieties and planting times. Where managers have a good knowledge of crop water needs, they only respond when the sprinkler system can deliver water as required to meet the crop water needs. Supply-driven irrigation system management is being promoted as an alternative. The goal of supply driven management is to provide a reliable water supply to farmers. Once the farmers are certain of the water supply, they can cultivate crops and adopt the sprinkler technologies according to the water supply.

\section{Water quality in sprinkler irrigation systems}

The suitability of irrigation water for crop production mainly depends on the amounts and type of salts present in water. Almost all water sources contain some level of dissolved salts and trace elements resulting from human activities and weathering of soil. Humans also impact the quality of irrigation water in many ways. For example, metals and chemical waste can be released into water sources as by-products of industry and mining activities. Many studies show that the yield of many irrigation schemes is low due to water logging and salination of the soil ${ }^{[50-52]}$. Many farmers in Ghana for instance, rely heavily on agrochemicals to boost crops production ${ }^{[53]}$. And because the demand for water has increased, wastewater and reclaimed wastewater are currently being used in irrigation. The health implication on crop production and humans posed by the situation is endless and far reaching. Two types of irrigation water quality issues occur ${ }^{[52,54]}$; (1) total salinity and sodium related salinity. The effect of salinity on crop yield is comprised of two stages ${ }^{[55-57]}$ first, crop yield does not decrease until a threshold value is reached, and second, it begins with a linear decrease in yield as salinity increases. 
Salinity limit water and nutrient absorption capacity of crops, caused by salty water or soil due to addition of saline water, poor drainage, or shallow water table. Plants in turn absorb the water through the process of osmosis, resulting in the movement of salt ions from the soil into the root tissue of plants. But water absorption in plant is restricted when the soil salinity is higher than the internal salinity of the plant, resulting in smaller plants, and yield reduction occur even where plant symptoms are minimal. In situations of higher salinity, plant tissue dies, causing a condition known as necrosis at the leaf edges. Saline water also leads to the accumulation of trace minerals of which is toxic to plants when their concentration exceeds the permissible levels.

Sodicity is the concentration of sodium relative to calcium and magnesium concentrations, which is widely used to describe the salinity of the irrigation water. Sodium adsorbs onto cation exchange in the soil, which causes the soil to breakdown into fine particles, resulting to low water permeability. This occurs in the case of soils with high percentage of smectite clay. The capacity for sodium to increase its concentration in relation to calcium and magnesium cations is calculated by the equation for sodium absorption ratio $^{[33,58,59]}$.

$$
S A R=\frac{N a^{+}}{\sqrt{\frac{C a^{+2}+M g^{+2}}{2}}}
$$

where, $\mathrm{SAR}$ is the absorption ratio of sodium; $\mathrm{Na}^{+}, \mathrm{Ca}^{+2}$ and $\mathrm{Mg}^{+}$is the concentrations of sodium, calcium and magnesium ions, respectively (med/l).

Forage crops are the most tolerable to salinity, followed by field crops, vegetable crops, and fruit crops. Boron is a main problem in many irrigated areas. Though an important nutrient, its high levels leads to plant toxicity, and concentrations should not exceed the permissible levels. It is projected that between 20 to 30 million ha of irrigated areas are affected by salinity ${ }^{[60,62]}$. A summary of the guidelines is presented in Table 4 below. Table 5 show summary of guidelines for the assessment of sodium hazard of irrigation water. Many studies refer to sodicity problems of irrigation water as permeability. At low sodicity, soil flocculation and aggregation is lost and permeability decreases. Low salt concentration less than $0.2 \mathrm{dS} / \mathrm{m}$ decreases the permeability resulting from high $S A R$.

Table 1 Salinity assessment guidelines of irrigation water ${ }^{[62]}$

\begin{tabular}{cccc}
\hline \multirow{2}{*}{ SAR range } & \multicolumn{3}{c}{ Limitation } \\
\cline { 2 - 4 } & None & Moderate & Severe \\
\hline $0-3$ & $>0.7$ & $0.2-0.7$ & $<0.2$ \\
$3-6$ & 1.2 & $0.3-1.2$ & 0.3 \\
$6-12$ & 1.9 & $0.5-1.9$ & $<0.5$ \\
$12-20$ & 2.9 & $1.3-2.9$ & 1.3 \\
$20-40$ & 5.0 & $2.9-5.0$ & $<2.9$ \\
\hline
\end{tabular}

Scheduling in sprinkler irrigation helps to minimize the incidence of excess leaching associated with excessive irrigation. A common water management practice to salinity problems is periodic leaching with ample irrigation water to leach salt below the crop root zone. Other practices include using well-drained soils and properly designed and constructed drainage system to dispose salty water from the soil ${ }^{[59,63-69]}$. As salinity level increase, the amount of irrigation water and frequency of application also has to increase. The leaching requirement $(L R)$ is calculated using the equation below:

$$
L R=\frac{\text { Conductivity of irrigation water }}{\text { Conductivity of soil in the crop rootzone }}
$$

The formula is used to determine the level of salinity when the amount of water needed for leaching is constant. However, because of irrigation inefficiencies additional irrigation water has to be applied to eliminate the remaining salts in the root zone. Chemical amendments is also used to improve sodic soil condition $^{[55,64-70]}$. For example, the use of gypsum contains calcium which amends saline soil conditions. Calcium exchanges the adsorbed Sodium which helps to reestablish the infiltration rate of the soil. But it is important to note that the use of chemicals does not disregard the leaching requirement. Hence, the application of additional water is necessary to leach out the displaced sodium ${ }^{[70-76]}$.

Irrigation water can be saved by optimizing the efficiency of sprinklers. Sprinkler irrigation is still an accepted practice for watering lawns although a study described a relatively low efficiency in applying water to the plants ${ }^{[77-79]}$. However, another study shows that salinity in drip irrigation was lower or similar to that measured in sprinkler irrigation, which means that drip irrigation compared with sprinkler irrigation is not more efficient in leaching salt from the soil ${ }^{[80-82]}$. Poorly spaced laterals and sprinklers, including losses by wind and evaporation increases the total water uses and reduces the quality in crop produce. When using sprinklers, the outer margin of each circular zone wetted by a single sprinkler nozzle receives less water than the center portion. Salt dissolved in irrigation water tends to move along with the water as the water flows through the soil. Figure 4 presents the pattern of salinity for the two cases indicated above. Figure $4 \mathrm{a}$ presents the layout of a line of sprinklers on a field. In Figure $4 \mathrm{~b}$ of the illustration, the wetted zones corresponding to the various sprinklers overlap considerably and the soil is wetted with a high uniformity. Conversely, the illustration shows a situation where the sprinkler heads are too far apart and overlap of the wetted zones is insufficient, resulting in non-uniform wetting of the soil (Figure 4a). To avoid such situation, the layout of lateral lines should be in a parallel fashion with sprinklers offset, to obtain good overlapping of the wetted zones.
0.8

\begin{tabular}{c}
\hline 1.1 \\
\hline 2.0 \\
\hline 2.7 \\
\hline 4.0 \\
\hline
\end{tabular}

a. Uniform application

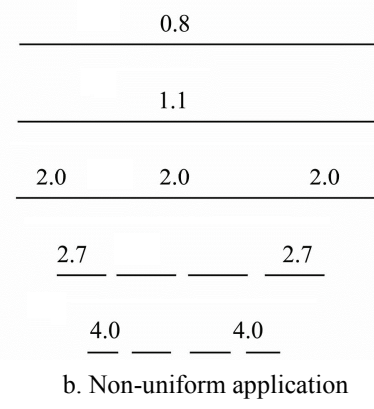

Figure 4 Water application from the lateral lines and layout of sprinkler system

Figure $4 \mathrm{a}$ is for the situation where sprinklers are close to one another that the wetted zones overlap, resulting in uniform application in the root zone. As expected, the salts are distributed uniformly in the horizontal direction. In the vertical dimension, however, the shallower portions of the root zone contain less salt than the deeper portions, as a result of the leaching fraction. The numbers on the diagram, represent the degree of salt concentration, which reveal that it tends to accumulate in the bottom soil depths. In Figure 3b, the sprinklers are far apart, resulting in non-uniform application in the root zone. The result is a non-uniform 
distribution of salt concentration in the horizontal and vertical directions. Using the non-uniform wetting as an example, the vertical distribution of salts in the wetted zone is identical to that for the uniformly wetted case except that in regions with insufficient sprinkler overlaps, the $L R$ is smaller and, hence, the salt concentration is higher.

The use of reclaimed water for irrigation is gaining considerable interest in many parts of the world. Smart irrigation controllers that incorporate soil moisture sensors for feedback control can improve performance, but there has been concern about using such control devices with reclaimed water, which can affect the soil dielectric permittivity and thus affect the values from the sensor device. A study on time-based irrigation control to control incorporating one of four different sensors as affected by both potable and reclaimed water ${ }^{[83]}$. Water savings using sensor devices averaged $63 \%$ and $59 \%$ for the potable and reclaimed water sources, respectively ${ }^{[81,84]}$. Hence, it can be concluded that the small accuracy reduction in sensors when using reclaimed water would be acceptable.

\section{Limitations of sprinkler irrigation}

1) Previous researches concentrated more on determining $\mathrm{ET}_{\text {crop }}$ using crop water uses under no stress conditions with no consideration for annual and perennial crops under different growth stages and stress conditions.

2) For $E T_{\text {crop }}$ controllers to be fully effective, the existing sprinkler irrigation system must be operated and maintained properly. How water savings estimates obtained from field trials be extrapolated to other areas with very different characteristics and/or weather patterns still remains under researched.

3) Water saved between weather-based and soil-moisture based "smart" controller, and how these circumstances favor one over the other are currently not known. Field evaluations report water saved in terms of percent reduction per crop without providing any sense for how these savings varied by different crop characteristics, such as total water use, irrigated area, longevity of saving, and level of wasteful irrigation prior to the retrofit. Without such information, however, others cannot extrapolate a study's results to their own service areas.

4) With sprinkler irrigation the saline water immediately gets into contact with the foliage. The indiscriminate absorption of ions by leaves leads to a decrease in photosynthesis or structural damage of the foliage. In addition, inaccurate spacing of sprinkler result in concentration of salts in certain areas in the field, which reduces crop yields. Beyond the permissible level, reduction in crop yield is relational to the increase in salinity level. Different crops vary in their degree of resistance to salinity and therefore have different permissible levels vis a vis reduction in yields.

\section{Conclusions and future perspectives}

The study explored major emerging technologies in sprinkler irrigation systems, and their significance in saving water to optimize crop production. To meet the cost of investment, it is also necessary to emphasize on continuous irrigation engineering and science with emerging technologies building on earlier knowledge and progress towards optimize crop production. The following actions are necessary from future perspectives

There is pressing need for research to determine the actual $\mathrm{ET}_{\text {crop }}$ for annual and perennial crop stages and stress conditions of annual crops in order to properly manage soil water deficits. Because of the high costs and difficulty of the relations with other factors that also influence $E T_{\text {crop. }}$ It is important to evaluate the $E T_{\text {crop }}$ values bearing in mind increase in soil salinity levels and the control of water stresses with attention to crop yields and quality.

It is important that future field evaluations build a "look forward" feature into their study design. It is not enough to estimate what a certain program saved in retrospect. It is also important to provide a way for others to assess that if program saved a certain amount of water in a given service area, how much is a similar program likely to save in another area with different socio-economic and weather characteristics. Future studies can make their findings more broadly applicable, in the bargain also improving the ability to dissect and compare an evaluation's results with those of other such evaluations.

The application technology has been developed for years but one of the remaining research areas in sprinkler irrigation is the development of optimized method for irrigation scheduling.

Optimisation of the fixed water dispersion devices for impact sprinkler to facilitate jet breakup under low pressure, producing a mist of droplets in mid-air, resulting in higher humidity and lower temperatures. The optimum fixed water dispersion device for impact sprinkler has the potential to increase the LR for leaching salt-based ion from the root zone of crops and meet crop water demand at the same time.

\section{Acknowledgements}

This work was supported by the National Natural Science Foundation of China $(51679109,51809119)$, the Natural Science Foundation of Jiangsu Province (BK20170555), the Natural Foundation of the Higher Education Institutions of Jiangsu Province (17KJB470001), Special Scientific Research Fund of Agriculture Public Welfare Profession of China (201503130).

\section{[References]}

[1] Intergovernmental Panel on Climate Change. Climate change and water. Technical paper of the intergovernmental panel on climate change. Geneva, Switzerland, 2008 .

[2] FAO. Cropwat 8.0 for windows user guide. Rome, Italy, 2009.

[3] International Food Policy Research Institute. Global nutrition report: actions and accountability to accelerate the world's progress on nutrition. Washington DC, USA, 2014.

[4] FAO. FAO statistical pocketbook. United Nations, Rome, Italy, 2015.

[5] United Nations. Wastewater the untapped resources. United Nations Educational, Scientific and Cultural Organization, 7, Place de Fontenoy, Paris, France, 2017.

[6] Yan H. Study on water distribution uniformity of center pivot and lateral move irrigation systems based on variable rate technology. China Agricultural University, Beijing, China, 2004.

[7] Siebert S, Döll P. Quantifying blue and green virtual water contents in global crop production as well as potential production losses without irrigation, J. Hydrol, 2010; 384: 198-217.

[8] Alexandratos N, Bruinsma J. World agriculture towards 2030/2050: The 2012 revision. ESA Working paper No. 12-03, Rome, Italy, 2012.

[9] Kannan S. Physiology of foliar uptake of inorganic nutrients. Proceedings: Plant Sciences, 1986; 96(6): 457-470.

[10] Kulkarni S. Innovative technologies for water saving in irrigated agriculture. International Journal of Water Resources and Arid Environments, 2011; 1(3): 226-231.

[11] Zou X, Li Y, Gao Q, Wan Y. How water saving irrigation contributes to climate change resilience: A case study of practices in China. Mitigation and Adaptation Strategies for Global Change, 2012; 17(2): 111-132.

[12] Xia J, Duan Q, Luo Y, Xie Z, Liu Z, Mo X. Climate change and water: Case Study on Eastern Monsoon Region of China, Advances in Climate Change Research, 2017; 8(2): 63-67.

[13] Robert G, Pat H, Shawn D, Askew L. Nozzles: selection and sizing Publication 442-032, Virginia, USA, 2013.

[14] Urrego-Pereira Y, Antonio F, Cavero M J. Relevance of sprinkler 
irrigation time and water losses on maize yield. Agronomy Journal, 2013; 105(3): 845-853.

[15] Nelson Irrigation. Irrigation technology for the future. Washington, USA, 99362, 2016.

[16] Wang Y, Sun P, Sun W, Wang T, Chong B. Key components design and experimental research of roll wheel line move irrigator. Northeast Agricultural University, Heilongjiang, China, 2016.

[17] Venkata N, Rohit G. Micro controller based automatic plant irrigation system. International Journal of Advancements in Research and Technology, 2013; 2(4): 194-198.

[18] Rahman A, Singh AK. A simple low-cost water sprinkling nozzle for field crop irrigation, Current Science, 2014; 107(1): 12

[19] Lingdi T. Numerical simulation on characteristics of secondary flow resistance for a hose reel irrigator. Jiangsu University, Jiangsu, China, 2013.

[20] Merriam J L, Keller J. Farm irrigation system evaluation: A guide to management. Utah State Univ, Logan,Utah, 1978.

[21] Phocaides A. Technical handbook on pressurized irrigation techniques, FAO, USA, 2007; pp.101-112.

[22] Ella V B, Reyes M R, Yoder R. Effect of hydraulic head and slope on water distribution uniformity of a low-cost drip irrigation system. Applied Engineering in Agriculture, 2009; 25(3): 349-356.

[23] Allen R G, Smith M, Pereira L S, Perrier A. An update for the calculation of reference evapotranspiration. ICID Bulletin, 1994; 43(2): 35-92.

[24] Li J, Li Y, Wang J, Wang Z, Zhao W. Microirrigation in china: history, current situation and prospects. Journal of Hydraulic Engineering, 2016; 47(3): 372 .

[25] Merkley G P, Allen R G. Sprinkle and trickle irrigation lecture notes, Utah State University, USA, 2004.

[26] Yisheng Z, Delan Z, Lin Z. Study on translocating speed and water distribution uniformity of lightweight lateral move irrigation system. Journal of Drainage and Irrigation Machinery Engineering, 2014; 32(7): 625-630.

[27] Hiler E A, Howell T A. Grain sorghum response to trickle and subsurface irrigation. Trans. ASAE, 1973; 16(4): 799-803.

[28] Howell T A, Gowda P H. The Bushland lysimeters: A quarter century of crop ET investigations to advance sustainable irrigation. Trans. ASABE, 2016; 59(1): 163-179.

[29] Allen R G. Demonstration of potential for residential water savings using a soil moisture controlled irrigation monitor, in water management and conservation activity, United States Bureau of Reclamation, Provo, Utah, 1997.

[30] Cardenas-Lailhacar B, Dukes M D, Miller G L. Sensor-based control of irrigation in bermudagrass, in American Society of Agricultural Engineers Annual International Meeting, Tampa, Florida, 2005.

[31] Dukes M D. Smart irrigation controllers: What makes an irrigation controller smart? Univ. Florida IFAS Ext. 1-3, 2012.

[32] Dukes M D. Water conservation potential of landscape irrigation smart controllers. Trans. ASABE, 2012; 55(2): 563-569.

[33] Mayer P W, DeOreo W B. Improving urban irrigation efficiency by using weather-based "smart" controllers. J American Water Works Association, 2010; 102(2): 86-97.

[34] Pittenger D R, Shaw D A, Richie W E. Evaluation of weather-sensing landscape irrigation controllers, Riverside, California, 2004.

[35] King B A, Stark J C, Wall RW. Comparison of site-specific and conventional uniform irrigation management for potatoes. Applied Eng in Agric, 2006; 22(5): 677-688.

[36] Speir A. Management of irrigation systems. The University of Georgia Cooperative Extension. Bulletin, 2009; pp.1152-1205.

[37] National Research Council. The national weather service modernization and associated restructuring: A Retrospective Assessment. National Academies Press, Washington, D.C. USA, 2012.

[38] Zhu T, Ringler C, Iqbal T B, Sulser M A. Climate change impacts and adaptation options for water and food in Pakistan: scenario analysis using integrated global water and food production model. Water International, 2013; 38(5): 651-669.

[39] Han W T, Cui L H, Wu P T. Calculation methods for irrigation uniformity with sprinklers spaced in regular triangle. Transactions of the CSAM, 2013; 44(4): 99-107. (in Chinese)

[40] Li H, Yuan S Q, Liu J, Zhang J Q, Zhu X Y, Xie F Q. Wall attachment fluidic sprinkler. Ch. Patent No. 10122444B, 2007.

[41] Letey J, Cardon G E I. Irrigation efficiency and uniformity. In: Miller R.J. \& Gardiner D.T. 2001. Soils in our environment. 9th Edition.
Prentice Hall-Inc., New Jersey, USA, 2007.

[42] Mansour HA, Abd El-Hady M. Performance of irrigation systems under water salinity in wheat Production. Journal of Agriculture and Veterinary Science, 2013; 7(7): 19-24.

[43] FAO. Irrigation in Africa in figures. AQUASTAT survey 2005 Edited by Karen Frenken. FAO Land and Water Development Division, Rome, 2005.

[44] Kyei-Okyere S. Determinants of crop water demand of mango in the transition zone of Ghana. Master's thesis, KNUST, Kumasi Ghana, 2009, 27-30.

[45] FAO. Cropwat: A computer program for irrigation Planning and Management, By M. Smith. FAO Irrigation and Drainage Paper No.46, Rome, 1992.

[46] FAO. Regional workshop on irrigation advisory and training services in the Near East. Regional Office for the Near East. Cairo, Egypt, 2002.

[47] FAO. FAO statistical pocketbook. United Nations, Rome, Italy, 2015.

[48] FAO. Solaw: The state of the world's land and water resources for food and agriculture. Rome, Italy, 2011.

[49] FAO. Irrigation in Africa in figures. AQUASTAT Survey 2005. Edited by Karen Frenken. FAO Land and Water Development Division, Rome, 2005.

[50] Mansour H A. Design considerations for closed circuits of drip irrigation system. PhD: Thesis, Faculty of Agriculture, Agric., Ain Shams University, Egypt, 2012.

[51] Lamm F R. Cotton, tomato, corn, and onion production with subsurface drip irrigation: A review. Trans. ASABE, 2016; 59(1): 263-278.

[52] Shearer M N, Vomacil J. Twenty-five tears of modern irrigation scheduling promotional efforts. In Proc. Irrig. Scheduling Water and Energy Conservation in the 80s. St Joseph, Mich, ASAE, 1981; pp.208-212.

[53] Migliaccio K W, Morgan K T, Velledis G, Zotarelli L, Fraisse C, Zurweller B A, et al. Smartphone apps for irrigation scheduling. Trans. ASABE, 2016; 59(1): 291-301.

[54] FAO. World agriculture: towards 2030/2050. Interim report. Prospects for food, nutrition, agriculture and major commodity groups. Rome, Italy, 2006.

[55] Oswald J K, Werner H D, Trooien T P. Automated water management for center-pivot irrigation systems. In Proc. 2005 Irrigation Association Intl. Exposition and Technical Conf., 349-356. Falls Church, Va.: Irrigation Association, 2005.

[56] Jones C A, Bland W, Ritchie J T, Williams J R. Simulation of roo growth. Modeling plant and soil systems, Hands J and Ritchie J T, Eds., ASA, Madison, Wis., 1991; pp.91-123.

[57] FAO. Cropwat 8.0 for windows user guide. Rome, Italy, 2009.

[58] Brewer J D, Kolavalli S, Kalro A H, Naik G, Ramnarayan S, Raju K V R. Irrigation management transfer in India: Policies, processes and performance, Indian Institute of Management, Ahmedabad, and International Irrigation Management Institute, Colombo, 1998.

[59] Brewer J D. Negotiating water allocation rules in a government managed irrigation system: Conflicts in Kirindi Oya, paper presented at the Meetings of the International Association for the Study of Common Property, June 5-8, Berkeley, CA, 1996.

[60] Brewer J D, Sakthivadive R, Raju K V. Water distribution rules and water distribution performance: A case study in the Tambraparani System, Research Report No. 12, International Irrigation Management Institute, Colombo, 1997.

[61] Jensen M E. Design and operation of farm irrigation systems. American Society of Agricultural Engineers, St. Joseph MI. 829, 1980.

[62] Jensen M E, Rangeley W R, Dieleman P J. Irrigation trends in world agriculture. Agronomy, 1990; 30: 31-67.

[63] Lagat M, Danson J, Kimani M, Kurani A. Quantitative traits loci for resistance of maize streak virus disease in maize genotype used in hybrids. Afr. J. Biotecnol, 2007; 7(14): 2573-2577.

[64] Amoah P, Drechsel P, Abaidoo R C, Ntow W J. Pesticides and pathogens contaminations of vegetables in Ghana's urban markets. Archives of Environmental Contamination and Toxicology, 2005; 50(1): 1-6.

[65] Plaut Z, Edelstein M, Ben-Hur M. Overcoming salinity barriers to crop production using traditional methods. Crit. Rev. Plant Sci., 2013, 32: 250-291.

[66] Maas E V, Hoffman G J. Crop salt tolerance-current assessment. Journal of the Irrigation and Drainage Division, 1977; 103: 115-134.

[67] Lee S B, Hong C O, Gutierrez J, Kim P J. Effect of irrigation water salinization on salt accumulation of plastic film house soil around Sumjin 
river estuary. Korean J. Environ. Agric, 2008; 27: 349-355.

[68] De Pascale S, Orsini F, Pardossi A. Irrigation water quality for greenhouse horticulture. In Good agricultural practices for greenhouse vegetable crops; FAO Plant Production and Protection Paper 217; Food and Agriculture Organization of the United Nations: Rome, Italy, 2013; pp.69-204.

[69] Kim H, Fonseca J M, Choi J, Kubota C, Kwon D Y. Salt in irrigation water affects the nutritional and visual properties of romaine lettuce (Lactuca sativa L.). J. Agric. Food Chem, 2008; 56: 3772-3776.

[70] FAO. Good Agricultural practices for greenhouse vegetable crops; FAO Plant Production and Protection Paper 217; Food and Agriculture Organization of the United Nations: Rome, Italy, 2013.

[71] Levy Y, Columbus D, Sadan D. Trickle linear gradient for assessment of the salt tolerance of citrus rootstocks in the orchard. Irrig. Sci, 1999; 18: 181-184.

[72] Yazgan S, Ayas S, Demirtas C, Büyükcangaz H, Candogan B N. Deficit irrigation effects on lettuce (Lactuca sativa var. Olenka) yield in unheated greenhouse condition. J. Food Agric. Environ., 2008; 6: 357-361.

[73] Western fertilizer handbook. California Fertilizer Association. 1700 Street, Suite 130, Sacramento, Ca, 1995.

[74] Khan S, Tariq R, Yuanlai C, Blackwell J. Can irrigation be sustainable? Agric. Water Mgmt, 2006; 80(1-3): 87-99

[75] Tanji K K. Agricultural salinity assessment and management. American Society of Civil Engineers. Manuals and reports on engineering practice, 1990; No.71. 619
[76] Shannon M C, Grieve C M. Tolerance of vegetable crops to salinity. Sci. Hortic., 1998; 78: 5-38.

[77] Rowe D R, Abdel Magid I M. Handbook of wastewater reclamation and reuse. CRC Press, Inc. 550, 1995.

[78] Rameshwaran P, Tepe A, Yazar A, Ragab R. The effect of saline irrigation water on the yield of pepper: Experimental and modelling study. Irrig. Drain, 2015; 64: 41-49.

[79] Mecham B. A summary report of performance evaluations on lawn sprinkler systems. Northern Colorado Water Conservancy District, Berthoud, CO, USA, 2004.

[80] Beltran J M. Irrigation with saline water: Benefits and environmental impact. Agric. Water Manag, 1999; 40: 183-194.

[81] Schiavon M, Leinauer B, Sevostianova E, Serena M, Maier B. Warm season turfgrass quality, spring green-up, and fall color retention under drip irrigation. Appl. Turfgrass Sci, 2011. doi: 10.1094/ATS2011-0422-01-RS

[82] O'Shaughnessy S A, Urrego Y F, Evett S R, Colaizzi P D, Howell T A. Assessing application uniformity of a variable rate irrigation system in a windy location. Applied Engineering in Agriculture, 2013; 29: 497-510.

[83] Feizi M, Hajabbasi M A, Mostafazadeh-fard B. Saline irrigation water management strategies for better yield of safflower (Carthamus tinctorius L.) in an arid region. Aust. J. Crop Sci, 2010; 4: 408-414.

[84] Dukes M D, Bjorneberg D L, Klocke N L. Advances in irrigation: Select works from the 2010 decennial irrigation symposium. Trans. ASABE, 2012; 55(2): 477-482. 